\title{
Regulation of pentose utilisation by AraR, but not XInR, differs in Aspergillus nidulans and Aspergillus niger
}

\author{
Evy Battaglia • Sara Fasmer Hansen • \\ Anne Leendertse • Susan Madrid • Harm Mulder • \\ Igor Nikolaev • Ronald P. de Vries
}

Received: 17 December 2010 /Revised: 15 March 2011 /Accepted: 15 March 2011 /Published online: 12 April 2011

(C) The Author(s) 2011. This article is published with open access at Springerlink.com

\begin{abstract}
Filamentous fungi are important producers of plant polysaccharide degrading enzymes that are used in many industrial applications. These enzymes are produced by the fungus to liberate monomeric sugars that are used as carbon source. Two of the main components of plant polysaccharides are L-arabinose and D-xylose, which are metabolized through the pentose catabolic pathway (PCP) in these fungi. In Aspergillus niger, the regulation of pentose release from polysaccharides and the PCP involves the transcriptional activators AraR and $\mathrm{X} \operatorname{lnR}$, which are also present in other Aspergilli such as Aspergillus nidulans. The comparative analysis revealed that the regulation of the PCP by AraR differs in A. nidulans and A. niger, whereas the regulation of the PCP by $\mathrm{X} \operatorname{lnR}$ was similar in both species. This was demonstrated by the growth differences on L-arabinose between disruptant strains for araR and $x \ln R$ in $A$. nidulans and $A$. niger. In addition, the expression profiles of genes
\end{abstract}

Electronic supplementary material The online version of this article (doi:10.1007/s00253-011-3242-2) contains supplementary material, which is available to authorized users.

E. Battaglia $\cdot$ A. Leendertse $\cdot$ R. P. de Vries

Department of Microbiology and Kluyver Centre for Genomics

of Industrial Fermentation, Utrecht University,

Padualaan 8,

$3584 \mathrm{CH}$ Utrecht, The Netherlands

S. F. Hansen $\cdot$ S. Madrid $\cdot$ H. Mulder $\cdot$ I. Nikolaev

Danisco Innovation,

Langebrogade 1,

Copenhagen 1001, Denmark

S. Madrid

Genencor/Danisco,

925 Page Mill Road,

Palo Alto, CA 94304, USA encoding L-arabinose reductase (larA), L-arabitol dehydrogenase $(\operatorname{lad} A)$ and xylitol dehydrogenase $(x d h A)$ differed in these strains. This data suggests evolutionary changes in these two species that affect pentose utilisation. This study also implies that manipulating regulatory systems to improve the production of polysaccharide degrading enzymes, may give different results in different industrial fungi.

Keywords Aspergillus nidulans · Aspergillus niger . Regulation $\cdot$ Pentose catabolic pathway

\section{Introduction}

Plant polysaccharide degradation by fungi has been a topic of study for many decades due to the relevance of these enzymes for various industrial applications (food and feed,

H. Mulder · I. Nikolaev

Genencor/Danisco,

Archimedesweg 30,

2333 CN Leiden, The Netherlands

R. P. de Vries $(\bowtie)$

CBS Fungal Biodiversity Centre,

Uppsalalaan 8,

3584 CY Utrecht, The Netherlands

e-mail: r.devries@cbs.knaw.nl

Present Address:

S. F. Hansen

Joint BioEnergy Institute, Feedstocks Division,

Lawrence Berkeley National Laboratory,

5885 Hollis St,

Emeryville, CA 94608, USA 
paper and pulp, detergents, beverages, bio-fuel, etc.). A detailed understanding of the regulatory systems that control the production of these enzymes in relevant fungi is essential to improve their production. For saprobic fungi, these systems are mainly aimed at liberating digestible carbon sources to support growth, and therefore, the hydrolysis of the polysaccharides is often linked to the metabolic conversion of the monomeric component. This is controlled at the transcriptional level by specific transcriptional activators and repressors, where the monomeric components of the polysaccharides are often the inducers of the transcriptional activators (de Vries and Visser 2001). Understanding the utilisation of the monomeric sugars will therefore also provide insight in the mechanism behind polysaccharide hydrolysis.

L-Arabinose and D-xylose are important components of the plant cell wall polysaccharides arabinan, arabinogalactan (substructures of pectin), xyloglucan and xylan. Aspergilli are able to release these pentoses from polysaccharides using a broad enzymatic system (reviewed by de Vries and Visser 2001). In Aspergilli, L-arabinose and D-xylose are catabolised through the pentose catabolic pathway (PCP; Witteveen et al. 1989). All corresponding genes and their regulation have been studied in Aspergillus niger (de Groot et al. 2007; Hasper et al. 2000; Mojzita et al. 2010a; Mojzita et al. 2010b; vanKuyk et al. 2001). Two regulatory systems that act in antagonistic fashion are involved in the PCP of $A$. niger, responding to D-xylose (xylanolytic regulator, XlnR; van Peij et al. 1998) and L-arabinose/L-arabitol (arabinolytic regulator, AraR; Battaglia et al. 2011).

$\mathrm{X} \operatorname{lnR}$ regulates the first step (D-xylose reductase, $x y r A$ ) of the D-xylose pathway (Hasper et al. 2000). AraR predominantly regulates the L-arabinose pathway specific reactions; the L-arabitol dehydrogenase encoding gene (ladA) is under the control of AraR and indications that the L-arabinose reductase and L-xylulose reductase encod- ing genes (larA and $\operatorname{lx} A$ ) are under regulation of the arabinolytic system have been reported (Battaglia et al. 2011; de Groot 2005). AraR and XlnR both regulate the common steps of L-arabinose and D-xylose catabolism (xdhA, xkiA; Battaglia et al. 2011; de Groot et al. 2007).

The presence of the genes of the PCP as well as $x \ln R$ and araR is conserved in Aspergillus species (Battaglia et al. 2011; Flipphi et al. 2009; de Vries et al. 1994), but it is not clear if their expression and mechanism are identical in these fungi. In this study, we characterized AraR from $A$. nidulans and analysed its regulatory role, together with $\mathrm{X} \operatorname{lnR}$, in the PCP. In addition, we compared these results to those previously reported for $A$. niger to demonstrate the differences between these two species.

\section{Materials and methods}

Strains, media and growth conditions

The A. nidulans and A. niger strains used in this study are listed in Table 1. The A. nidulans AN031 strain was obtained from Prof. C. Scazzocchio (Institut de Genetique et Microbiologie, Orsay, France). A. niger and A. nidulans were grown in minimal medium (MM) or complete medium (CM; de Vries et al. 2004). For the growth of auxotrophic strains, the medium was supplemented with $0.2 \mathrm{~g} / 1$ arginine, $0.2 \mathrm{~g} / 1$ leucine, $0.2 \mathrm{~g} / 1$ uridine and/or $1 \mathrm{mg} / 1$ nicotinamide. Agar was added at $1.5 \%(w / v)$ for solid medium. Liquid cultures were inoculated with $5 \times 10^{6}$ spores $/ \mathrm{ml}$ and incubated on a rotary shaker at $220 \mathrm{rpm}$. Solid medium plates were inoculated with $1 \times 10^{3}$ spores. A. nidulans was cultivated at $37^{\circ} \mathrm{C}$ and $A$. niger, at $30^{\circ} \mathrm{C}$.

For transfer experiments, $A$. nidulans was grown for $16 \mathrm{~h}$ at $37{ }^{\circ} \mathrm{C}$ in $\mathrm{CM}$ with $1 \%$ D-fructose, after which mycelia

Table 1 Aspergillus strains used in this study

\begin{tabular}{|c|c|c|c|c|}
\hline Strain & CBS number & species & Genotype & Reference \\
\hline AN031 & 129193 & A. nidulans & pyrG89, $\arg B 2$ & Prof. C. Scazzocchio \\
\hline Reference & 129194 & A. nidulans & $\operatorname{pyr} G 89, \arg B 2, p C D A 21(p y r G+)$ & This study \\
\hline$\triangle a r a R$ & 129195 & A. nidulans & $\operatorname{pyr} G 89, \arg B 2, \Delta \operatorname{araR}:: \operatorname{pyr} G$ & This study \\
\hline$\Delta x \ln R$ & 129196 & A. nidulans & $\operatorname{pyr} G 89, \arg B 2, \Delta x \ln R: \because \arg B$ & This study \\
\hline$\Delta \operatorname{araR} / \Delta x \ln R$ & 129197 & A. nidulans & $\operatorname{pyr} G 89, \arg B 2, \Delta \operatorname{araR}:: \operatorname{pyr} G, \Delta x \ln R: \because \arg B$ & This study \\
\hline Reference UU-A049.1 & & A. niger & $\begin{array}{l}\operatorname{csp} A 1, \text { pyrA6, nicA1, leuA1, } \\
\quad \triangle \arg B:: p I M 2101(\arg B+)\end{array}$ & Battaglia et al. (2011) \\
\hline$\triangle \operatorname{araR}$ UU-A033.21 & & A. niger & $\begin{array}{l}\operatorname{csp} A 1, \text { pyrA6, nicA1, leuA1, } \\
\quad \Delta \arg B:: \operatorname{pIM} 101(\arg B+), \Delta \operatorname{araR}\end{array}$ & Battaglia et al. (2011) \\
\hline$\Delta x \ln R$ UU-A062.10 & & A. niger & $\begin{array}{l}\operatorname{csp} A 1, \Delta \arg B, \operatorname{nic} A 1, \text { leuA, pyrA6:: } \\
\text { A. oryzae pyrA, } \Delta x \ln R\end{array}$ & Battaglia et al. (2011) \\
\hline$\Delta \operatorname{araR} / \Delta x \ln R$ UU-A063.22 & & A. niger & $\begin{array}{l}\operatorname{csp} A 1, \text { nicA1, leuA1, } \triangle \arg B:: \text { pIM2101 }(\arg B+) \\
\Delta \text { araR, pyrA6::A. oryzae pyrA, } \Delta x \ln R\end{array}$ & Battaglia et al. (2011) \\
\hline
\end{tabular}


aliquots were transferred to MM containing either $25 \mathrm{mM}$ D-fructose, L-arabitol, D-xylose, xylitol or $25 \mathrm{mM}$ L-arabinose. After 2 and/or $4 \mathrm{~h}$, the mycelium was harvested, frozen in liquid nitrogen and stored at $-80{ }^{\circ} \mathrm{C}$. For chromosomal DNA isolation, the strains were grown overnight in CM containing $2 \%$ D-glucose and the necessary supplements. The mycelium was harvested and frozen in liquid nitrogen.

\section{Molecular biology methods}

General methods were performed according to standard procedures (Sambrook and Russell 2001), unless stated otherwise. For chromosomal DNA isolation, a standard phenol-chloroform extraction method was performed. For PCR and Southern blot analysis, 50-100 ng and 5-10 $\mu \mathrm{g}$ of chromosomal DNA were used, respectively. DNA fragments were amplified using an Expand High Fidelity PCR Amplification System (Roche). The $50 \mu$ reaction mixture contained $5 \mu \mathrm{l}$ of $10 \times$ Expand buffer, 3.5 units of the Expand DNA polymerase mixture, $200 \mu \mathrm{M}$ dNTP mixture, $50 \mathrm{ng}$ of a DNA template and $40 \mathrm{pmol}$ of each primer. The ligations were performed using a Rapid Ligation Kit (Roche). The ligation mixtures were used to transform Escherichia coli One Shot ${ }^{\circledR}$ Top 10 competent cells. The transformants were selected on LB plates with $50 \mu \mathrm{g} / \mathrm{ml}$ of kanamycin. The plasmids and the primers used for DNA cloning are listed in Supplemental Table 1.

For the construction of plasmid pSFH1, araR was amplified with primers R1.7 T40 and R1.7 B3795. The PCR product was cloned into the $\mathrm{pCR}^{\circledR}$-Blunt II-TOPO ${ }^{\circledR}$ (Invitrogen). To generate the deletion of $\triangle \operatorname{araR}$, the araR 5' flanking region was amplified with primers R1.7 SpeI T603 and R1.7 NdeI B4008. The PCR product was digested with SpeI/NdeI and used to replace the 546 bp SpeI/NdeI fragment of pSFH1. This construct was subsequently digested with $N d e \mathrm{I} /$ BstZ17I, and both ends were made blunt by Klenow DNA polymerase I fragment (Roche). The Aspergillus fumigatus pyrG gene $(1.9 \mathrm{~kb})$, digested by EcoRV from the pCDA21 vector (Chaveroche et al. 2000), was ligated in the $N d e \mathrm{I} / B s t \mathrm{Z} 17 \mathrm{I}$ blunted vector, generating vector $\mathrm{pSFH} 3$. In the deletion construct, the $p y r G$ gene replaces $214 \mathrm{bp}$ of the $5^{\prime}$ flanking sequence upstream of the ATG codon and $301 \mathrm{bp}$ of the coding part including the $\mathrm{Zn}_{2} \mathrm{Cys}_{6}$ binuclear cluster.

The deletion of $x \ln R$ coding region was performed by insertion of the $\arg B$ gene between the flanking regions of $x \ln R$. The $5^{\prime}$ and $3^{\prime}$ flanking regions (1.8 and $2 \mathrm{~kb}$, respectively) were amplified by PCR with the primers $x \ln R$ T245 XhoI, $x \ln R$ B2067 KpnI, $x \ln R$ T3501 BamHI and $x \ln R$ B5510 NotI. The PCR product of the 5 ' flanking region was digested with $X h o \mathrm{I} / K p n \mathrm{I}$, and subsequently ligated into pUC21 (Vieira and Messing 1991). The construct was digested with BamHI/NotI and used for the insertion of the
3' $x \ln R$ PCR fragment. The resulting vector was digested with $K p n \mathrm{I} /$ Bam HI and used for insertion of the $A$. nidulans $\arg B$ gene $(2.4 \mathrm{~kb})$. This gene was amplified by PCR using primers $\arg B$ T1 KpnI and $\operatorname{argB}$ B2690 BamHI and plasmid pIC20-arg as template DNA. The resulting plasmid pSFH4 was used to transform $A$. nidulans.

The primers used to generate probes for Northern analysis are listed in Supplemental Table 1. The probes were DIG-labelled using the PCR DIG Probe Syntheses Kit (Roche Applied Science) according to the supplier's instructions.

Total RNA was isolated from powdered mycelium using a standard RNA isolation method with the TRIzol Reagent (Invitrogen). For Northern analysis, $3 \mu \mathrm{g}$ total RNA was transferred to a Hybond- $\mathrm{N}^{+}$membrane (Amersham Biosciences). Equal loading was determined by staining the blot for $5 \mathrm{~min}$ with $0.04 \%$ methylene blue, $0.5 \mathrm{M}$ acetate $\mathrm{pH} 5.2$ solution. The hybridization of the DIG-labelled probes was performed according to the DIG user's manual (www.roche-applied-science.com). All blots were incubated overnight at $50{ }^{\circ} \mathrm{C}$. The blots were exposed for $25 \mathrm{~min}$ up to $3 \mathrm{~h}$ to a Lumi-Film Chemiluminescent Detection Film (Roche Applied Science).

Transformation procedure and sexual crossing

The $A$. nidulans pyrG89 $\operatorname{argB2}$ recipient (AN031) strain was used for deletion of $\operatorname{araR}$ and $x \ln R$. A standard method of sorbitol/PEG transformation was applied (Tilburn et al. 1983). Transformants were screened for impaired growth on $\mathrm{L}$-arabinose or a loss of $\beta$-D-xylosidase activity in a plate test with 4-methylumbelliferyl- $\beta$-D-xyloside for $\triangle a r a R$ and $\Delta x \ln R$ deletions, respectively. The sexual cross of the strains $\triangle \operatorname{araR}(\operatorname{argB2})$ and $\Delta x \ln R($ pyrG89) was performed as described previously (Todd et al. 2007). Prototrophs were isolated as $\triangle a r a R \Delta x \ln R$ double deletions for further analysis.

\section{Genomic cluster comparison}

The conservation of the genomic region flanking araR across ten Aspergillus genomes was visualized using Sybil, a web-based software for comparative genomics (Crabtree et al. 2007). The genomic sequence data and the Sybil comparative visualization tool were accessed through the Aspergillus genome database (AspGD; http:/www. aspgd.org). The Aspergillus genomes used in the comparison comprised $A$. nidulans FGSC $\mathrm{A} 4, A$. niger $\mathrm{CBS}$ 513.88, A. niger ATCC 1015, Aspergillus terreus NIH2624, Aspergillus oryzae RIB40/ATCC 42149, Aspergillus flavus NRRL 3357, Aspergillus clavatus NRRL 1, Neosartorya fischeri NRRL 181, A. fumigatus A1163 and A. fumigatus Af293. 
Enzymatic assays

The cell-free extract was prepared by adding $1 \mathrm{ml}$ extraction buffer $\left(50 \mathrm{mM} \mathrm{K}_{2} \mathrm{HPO}_{4}, 5 \mathrm{mM} \mathrm{MgCl}_{2}, 5 \mathrm{mM} 2-\right.$ mercaptoethanol, $0.5 \mathrm{mM}$ EDTA) to the powdered mycelium. The mixtures were centrifuged for $10 \mathrm{~min}$ at $12,000 \mathrm{rpm}$ at $4{ }^{\circ} \mathrm{C}$. Intracellular enzyme measurements and activity calculations were performed as described previously (Battaglia et al. 2011). L-Xylulose reductase (Lxr) activity was determined using $50 \mathrm{mM}$ Tris buffer ( $\mathrm{pH} 7.8), 0.2 \mathrm{mM}$ NADPH and $4.5 \mathrm{mM}$ L-xylulose. The absorbance changes were measured at $340 \mathrm{~nm}$ in a Spectronic Unicam UV1 spectrophotometer.

Absorbance measurements were performed in triplicate. One unit of activity equals the conversion of $1 \mathrm{mmol}$ of substrate per minute. Total protein concentrations were determined using a BCA protein assay kit (Pierce).

\section{Results}

Identification of A. nidulans AraR

BlastP analysis of $A$. niger AraR (An04g08600) revealed a close ortholog (AN0388.4) in A. nidulans. AN0388.4 is found on contig 7, which is located on chromosome VIII. BLAST alignment of $A$. niger and $A$. nidulans AraR revealed $70 \%$ DNA and $77 \%$ amino acid identity.

The genomic region surrounding this gene is conserved in the eight Aspergilli that were analysed (Fig. 1). The alignment of AraR proteins from eight Aspergilli showed highly conserved regions, particularly in the DNA-binding domain and C-terminal region (Fig. 2). The region between the second and third cysteine is nearly identical between AraR from $A$. niger $\left(\mathrm{C}_{2} \mathrm{HARRVRC}_{3}\right)$ and $A$. nidulans $\left(\mathrm{C}_{2} \mathrm{HSRRVRC}_{3}\right.$; Fig. 2) and differs significantly from this

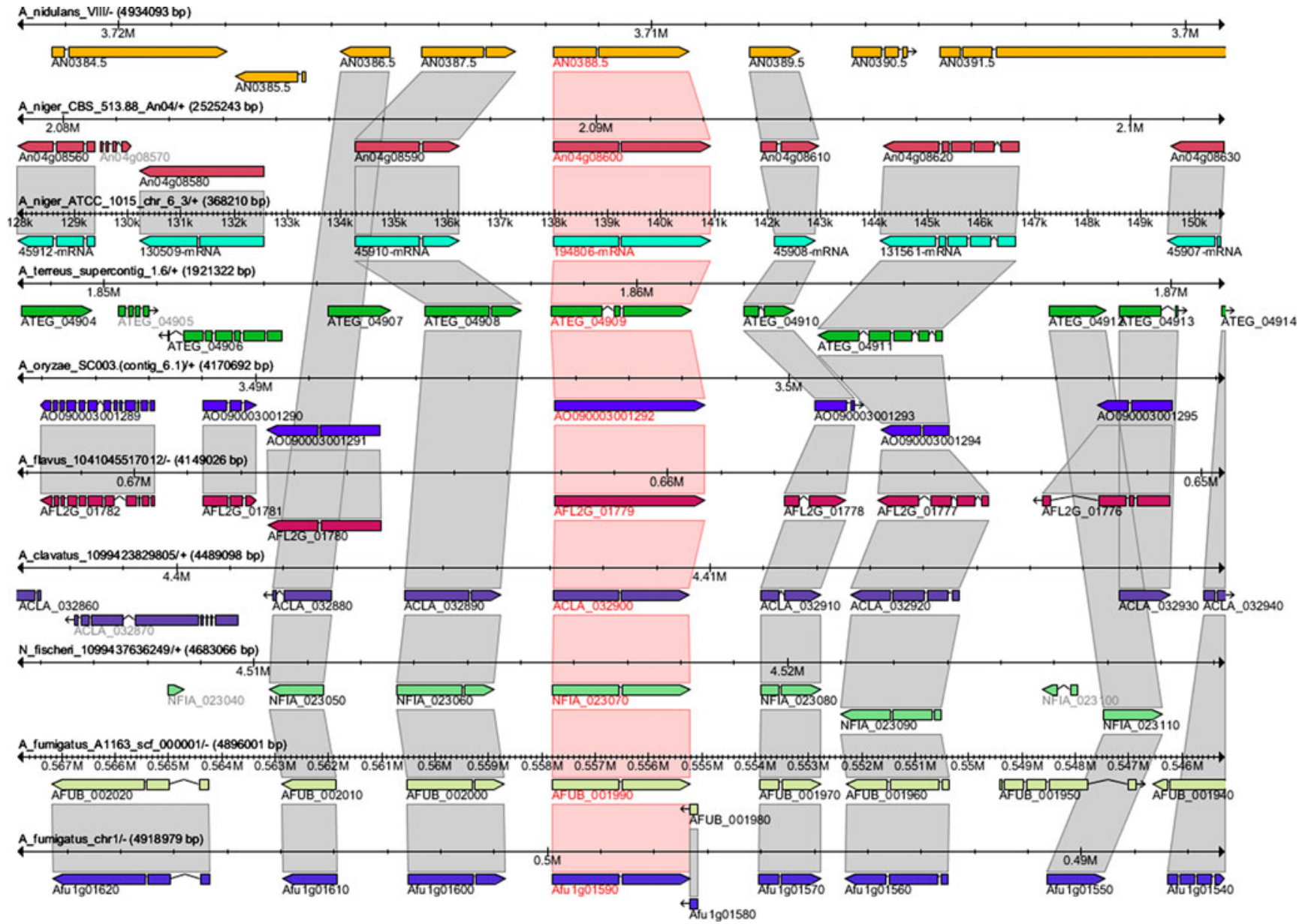

Fig. 1 Orthologous gene cluster of AraR. Graphic presentation of the genomic region of $A$. nidulans araR and comparison to other Aspergilli (Crabtree et al. 2007). AN0384 conserved serine rich protein, AN0385 putative branched-chain amino acid transaminase, AN0386 conserved hypothetical protein, AN0387 DNA photolyase, AN0388 AraR, AN0389 and AN0390 conserved hypothetical proteins, AN0391 NACHT domain-containing protein. The araR genes are connected by pinkshaded boxes. Nearby genes (in the 10-kb region on each side of araR) are shown, and those that are conserved are connected by grey-shaded boxes 
region in $\mathrm{X} \operatorname{lnR}$ in both species $\left(\mathrm{C}_{2} \mathrm{NQLRTKC} \mathrm{C}_{3}\right)$. This region was demonstrated to determine DNA-binding specificity in several zinc cluster proteins (Marmorstein et al. 1992; Marmorstein and Harrison 1994; Swaminathan et al. 1997; Walters et al. 1997).

Phenotypic comparison of $A$. niger and A. nidulans $\triangle$ araR and $\triangle \operatorname{araR} / \Delta x \ln R$

We constructed $\operatorname{araR}, x \ln R$ and double $(\operatorname{araR} / x \ln R)$ disruptant strains and verified them by Southern analysis (Suppl. Fig. 1). The growth was analysed in these strains on D-glucose, L-arabinose, L-arabitol, D-xylose and xylitol. The deletion of $x \ln R$ in both $A$. nidulans and A. niger did not affect growth on the tested carbon sources. The growth of the other deletion strains revealed significant differ-

Fig. 2 Multiple sequence alignment of AraR. The following amino acid sequences are aligned by ClustalW (Chenna et al. 2003): Neosartorya fischeri (NFIA023070), Aspergillus fumigatus (Afu1g01590), Aspergillus clavatus (ACLA032900), Aspergillus niger (An04g08600), Aspergillus nidulans

(AN0388.3), Aspergillus oryzae (AO090003001292), Aspergillus flavus (AFL2G01779.2) and Aspergillus terreus (ATEG04909.1). Conserved amino acid residues are shown in grey. Single asterisk indicates identical residues. Semi-colon indicates conservative substitutions. Period indicate less conservative substitutions. Cysteine residues are indicated in green. Fungal-specific transcriptionfactor domain of unknown function (Suarez et al. 1995) is shown in yellow
NFIA023070

Afulg01590 ACLA032900 An 04908600 AN0388.3

A0090003001292

AFL2G01779.2

ATEG04909.1

NFIA023070

Afulg01590

ACLA032900

An 04908600

AN0 388.3

A0090003001292

AFL2G01779.2

ATEG04 909.1

NFIA023070

Afulg01590

ACLA032900

An 04908600

AN0 388.3

A0090003001292

AFL2G01779. 2

ATEG04909.1

NFIA023070

Afulg01590

ACLA032900

An 04908600

AN0388.3

A0090003001292

AFL2G01779.2

ATEG04 909.1

NF IA023070

Afu1g01590

ACLA0 32900

An 04908600

AN0388.3

AO090003001292

AFL2G01779. 2

ATEG04 909.1

NFIA023070

Afu1g01590

ACLA032900

An04g08600

AN0388.3

A0090003001292

AFL2G01779. 2

ATEG04 909.1 ences between $A$. niger and $A$. nidulans (Fig. 3). The growth of the $A$. nidulans $\triangle$ araR strain was nearly impaired on L-arabinose, but only a small growth reduction was observed on L-arabitol. In contrast, the $A$. niger $\triangle a r a R$ strain showed only a small growth decrease on L-arabinose, while the growth on L-arabitol was strongly reduced. Both $A$. nidulans and A. niger $\triangle a r a R /$ $\Delta x \ln R$ strains showed strongly impaired growth on $\mathrm{D}$ xylose. Surprisingly, the growth of the $A$. nidulans $\triangle \operatorname{araR} / \Delta x \ln R$ strain was only slightly affected on Larabinose, whereas the growth was absent on this carbon source in the $A$. niger $\Delta a r a R / \Delta x \ln R$ strain. Furthermore, the absence of AraR and/or XlnR in A. nidulans did not affect the growth on xylitol, whereas the growth was reduced on this carbon source in the A. niger $\triangle \mathrm{araR} /$ $\Delta x \ln R$ strain.

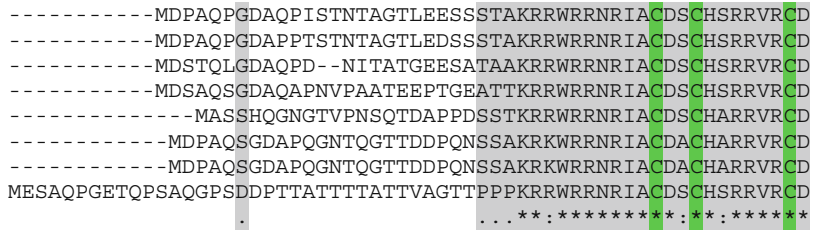

RAFPCSRCLRSEIRCEFTRERRKRGRIARSKQTAAVTNGGSMEKL- - - - - - SKAPNVQ RAFPCSRCLRSEIRCEFTRERRKRGRIARSKQTATVPNGGSMEKL - - - - - - - PKAPNVQ RAFPCSRCLRSE I HCEFTRERRKRGRIARSKQVPPATNEDTVEKR - - - - - - - PAAP - - RAFPCSRCLRSDIRCEFTRERRKRGRIARSRLVETKT-AVEKASQPVETRDSAP - - - - - RQFPCSRCLRSEITCEFTRERRKRGRIARSKLAEMAKNKMETSETPAPAKTMNG - - - - - RAFPCSRCLRSEIQCEFTRERRKRGRIARSKQTNTNGGTEKLSAALSNGRVPAPSTAD - RAFPCSRCLRSEIQCEFTRERRKRGRIARSKQTNTNGGTEKLSAALSNGRVPAPSTAD - RAFPCSRCLRSDIRCEFTRERRKRGRIARSRQTENTGTAGAITTEKTTATTATKPLPP RAFPCSRCLRSDIRCEFTRERRKRGRIARSRQTE
$\star * \star * * * * * * * * * * * * * * * * * * * * * * * *$

PPVPAAVPADAAPTPVPNHASPTTTFQQRSPATNEMTVSAHSIDDRRSQADPSLPAQRPG PPVPAAVPADAAPTPLPNHASPTTSFQHRSPATNEMTVSAHS IDDRRSQADPSLPARRPG - . - - - ATADPAGTPVINHASPTMPFPHRSPATNVTSASAPS IDGRRSOAELSLPPRRPG - - - - - APAEAGSGPVPNGSPSSTFHHRSPATNDVTGSAPSIDERRSQADVSLPPRKSG - - - - - I I PAPAGTEI PGHVSPASTFHHRS PPANAPTVSAPSVDGRRSQTDPQLPVRRPE - - - - - AGGDAVATPAPNGSPSSSFPHRSPGTNEMTASAPSVDERRSQAELPLAPRKLA - . - . - AGGDAVATPAPNGSPSSSFPHRSPGTNEMTASAPSVDERRSQAELPLAPRKLA - - - - - SIESVLTPIAQHESPSSTFPHRSPATNEMTASAASVDGRRSQAEISLPPPQPR .: : $: * *:$ : : :** :* : ***:*****: : . :

P - - - - TGNVTEEWLSAAHVSPDSYEVLGG - - GAWGDGPLPRVLDIWNGADLAGYSAPT P- - - - TGNVTEEWLSAAHVSPDSYEVLGG - - GAWGDGPLPRVLDIWNGADLAGYSAPT P - - - - NGNVTEEWLSAAHVSPESHEVLSG - - AGWADGPLPRVLDIWNGVDLVGYGAPT H- - - - TVNATEEWLAGTHVSPGSYEPLAG - - IGPGEGPFPRIFDIWNGVDLAGYSDPA I - - - - - GGNVTEEWLAGTHVSPGSYEFLNGP -AFGEGLGPFPHMFDVWNGVDLAAYSAGT P- - - - GGNVTEEWLAAAHVS PGSYDFLGGG - - - LGEGPFPRMFDVWSGVDLSNNSGPT P - - - - GGNVTEEWLAAAHVSPGSYDFLGGG - - - LGEGPFPRMFDVWSGVDLSNNSGPT RSVPDGNNNATEEWLSGTHVSPGSYEFLGGGG - - - LGDGPFPRMFDVWNGVDLAGYGAPT $* . * * * * *: .: * * * * *:: * *$

. **:*:: :**.*.** : :

VQGSKPAGAARAPS ISSTTLKYPVLQPLMPFLEANLPRRLVFDLLELYFTSAFSTHMHPV VQSSKPAGAARAPS ISSTTLKYPVLQPLMPFLEANLPRRLVFDLLELYFTSAFSTHMHPV AQGSKTASTTKTSSASAPDLKYPVLQPLMPFLEANLPRRLVFDLLELYFTSAFSTHMHPV SQGSKITGLGQTPAPSATILKYPVLQPVMPYLESSLPRKLVYDLLDLYFTSAFSTHMHPV SQGSKAT - - NAPSTSTAPLKYPVLQPLMPFVEATLPRKLVFDLLDLYFTSAFSTHMHPV POGAKVSGAGOTPGVPPASLKYPVLOPLMPFLDANL PRRLVFDLLELYFTSAFSTOMHPV PQGAKVSGAGQTPGVPPASLKYPVLQPLMPFLDANLPRRLVFDLLELYFTSAFSTQMHPV PRGNKPSSIGQPP - - PVALKYPVLQPLMPFLDANMPRRLVFDLLELYFTSAFSTHMHPV

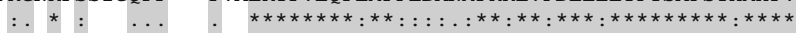

CHHIHCYVLRKASFLSRENPRPSSPALLASMLWVAALDDRAFALS ISPPQRKKICQFLCA CHHIHCYVLRKASFLSRENPRPSSPALLASMLWVAALDDRAFALS ISPPORKKICOFLCA CHHIHCYVLRKASFLSKEDPRPSSPALLASMLWVAALDDRAFALS ISPPQRKKICQFLCA CHHIHCYVLRKASFLSREAPRPS SPALLASMLWVAALDDRAFALPISPPQRKKICQFLCA S- - - - - - - FLSKDAPRPSSPALLSSMLWVAALDDRAFSLPISPPQRKRICQFLCA CHHIHSYILRKASFLSRDAPRPSTPALLASMLWVAALDDRAFALS ISPQQRKNICQFLCA CHHIHSYILRKASFLSRDAPRPSTPALLASMLWVAALDDRAFALS ISPOQRKNICQFLCA CHHIHCYVLRKASFLSRDNPRPSSPALLARDWSVRPDLSMMLLPISMSPRS - - - - - - - - 
Fig. 2 (continued)
NFIA023070 Afulg01590 ACLA0 32900 An 04908600
AN0 0388.3 AN0 388.3
AO0 90003001292 AFL2G01779. 2 ATEG04909.1

NFIA023070 Afulg01590 ACLA 032900 An 04908600 AN0388.3 A0090003001292 AFL2G01779.2 ATEG04909.1

NFIA023070 Afulg01590 ACLA 032900 An 04908600 AN0388.3 A0090003001292 AFL2G01779.2 ATEG04909.1

NFIA023070 Afulg01590 ACLA0 32900 An 04908600 AN0388.3 A0090003001292 AFL2G01779. 2

ATEG04909. 1

NFIA023070 Afulg01590 ACLA0 32900 An 04908600 AN0388. 3 A0090003001292 AFL2G01779. 2 ATEG04909.1

NFIA023070 Afulg01590 ACLA0 32900 An 04908600 AN0388.3 A0090003001292 AFL2G01779. 2 ATEG04909.1

NFIA02 3070 Afulg01590 ACLA0 32900 An 04908600 AN0388.3 A0090003001292 AFL2G01779. 2 ATEG04909.1

NFIA023070 Afulg01590 ACLA 032900 An 04908600 AN0 388.3 A0090003001292 AFL2G01779.2

ATEG04909.1

NFIA023070 Afu1g01590 ACLA0 32900 An 04908600 AN0388.3 AO090003001292 AFL2G01779. 2 ATEG04909.1
LTIRLLRPLIHVSFKEQAG-......- SNANDPTFTGVAPDCPPTTVHHPFESSGDDR LTIRLLRPLIHVSFKEQAG - - - - - - SNASDPTFTGVAPECPPTTVHHPFESSGDDR LTIRLLRPLIHVSFKEEGG - . - . - . - - PAAGDPPFPGVGPDCPPTTGHHPFESSGDDR LTLRLLRPLIHVSFKEO - . - . - . - EGAAASDPLHAAVGODGPPTTVHHPFEVGGDDR LTIRLLRPLIHVSFKDQGGAAAAVAAAAAAATNNPAFAGVGQDLPPTTVHHPFEGGGDDR LTIRLLRPLIHVSFKDQGA - . - . - . . - . - SLSEPVGQELPPTTVHHPFEGGGDDR LTIRLLRPLIHVSFKDQGA - . - . - . - . - - SLSEPVGQELPPTTVHHPFEGGGDDR L

GLVGPAGSLDDVITYIHVAS I ISSSEQKAASMRWWHAAFTLARELKLNQEIEVI PNADGQ GLVGPAGSLDDVITY IHVAS I ISSSEQKAASMRWWHAAFTLARELKLNQEI IVI PNADGQ GLVGPAGSLDDV ITY IHVAS I I SS EQKAASMRWWHAAFTLARELKLNQE I EMMPNVEGQ GLVGPAGSLDDVITYIHVAS I ISSSEQKAASMRWWHAAFTLARELKLNQEIEVMPSEENH GLVGPAGSLDDVITY IHVAS I ISSSEQKAASMRWWHAAFTLARELKLNQEI EVMPNGDSQ GLVGPAGSLDDVITY IHVAS I ISSSEOKAASMRWWHAAFTLARELKLNOEIEVLPNVDTO GLVGPAGSLDDVITYIHVASI ISSSEQKAASMRWWHAAFTLARELKLNQEIEVLPNVDTQ

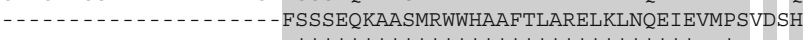
$: * * * * * * * * * * * * * * * * * * * * * * * * * * *:: *$ : : :

TEGSSPAFDYSLPGWSGVDTGAFFDYSNPTRPSLNCVCDRSHDPHATITEEHREERRRTW TEGSSPAFDYSLPGWSGVDTGAFFDYSNPTRPSLNCVCDHSHDPHATITEEHREERRRTW PEGSSPAFDYSLPGWSGVDTGAFFDYSNPTRPSLNCVCDRSHDPHVPITEEHREERRRTW PEGSSPAFDYSLPGWSGVDTGAFFDYSNPTRPSLNCVCDRSHDPHVPITEEHREERRRTW
PEGSSPSFDYSLAGWSGVDTGPFFDYSNPARPSLNCVCDRGHELRGAITEEHREERRRTW VEGSSPPFGYSLPGWDGADPGPVFNYSNPTRSSLNCVCDR - - QDQNTITEEHREERRRTW TEGSSPSFDYALPGWNGVETRPFFDFSNPTRPSLNCVCDR-HDMHNTITEEHREERRRAW TEGSSPSFDYALPGWNGVETRPFFDFSNPTRPSLNCVCDR - HDMHNTITEEHREERRRAW

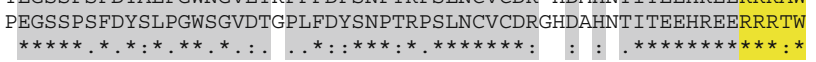

WLLY IMDRHLALCYNRPLALLDAESEDLLLPLDEGSWQAGNVHSNSPKPDGPHCPISGDK WLLY IMDRHLALCYNRPLALLDAESEDLLLPLDEGSWQAGNVHSNSPKPDGPHCPISGEK WLLY IMDRHLALCYNRPLALLDAESEDLLLPLDEGLWQAGNVHSNSPKPDGPQCSIAGDK WLLY IMDRHLALCYNRPLALLDAESEDLLLPLDEGSWQSGNIHSNSPKPDGPQCPLSGEK WLLY IMDRHLALCYNRPLALLDAESEDLLLPLDEASWQSGI IHSNSPKSDGPQCLLSADK WLLYIMDRHLALCYNRPLALLDAESEDLLLPLDEGSWQSGNIHSNSPRPDGPQCLLSGDK WLLYIMDRHLALCYNRPLALLDAESEDLLLPLDEGSWQSGNIHSNSPRPDGPQCLLSGDK WLLY IMDRHLALCYNRPLALLDAESEDLLLPLDEGSWQGGNIHSNSPKPDGPQCPLSGDK $* * * * * * * * * * * * * * * * * * * * * * * * * * * * * * . * * *:_{* * * * *} \cdot * * *: *:::^{*}$

NKRRVFPDFICHDHS IFGFFLPLMTITGELIDLNQARNHPMLGSRLHGKDGWDAHLSEVL NKRRVFPDF I CHDHS I FGFFLPLMT ITGELIDLNQARNHPMLGSRLHGKDGWDAHLSEVL TKRRVFPDFTCHDHS I FGF FLPLMT ITGELIDLNQARNHPMLGSRLNGKNAWDAHLREVL NKRRVF PNF I CHDHS I FGFFL PLMTITGEL IDLNOARNHPMLGARLNGKDPWDAHVGEVL NKRRLFPNF I CHDHSVFGFFLPLMT ITGEL IDLNQARNHPMLGMRLNGKDAWNVHVSEVL
NKRRVFPNFVCHDHS I FGFFLPLMT ITGELIDLNQSRNHPMLGVRLNGKDAWDVHVNAVL YKRRVF PNFVCHDHS I FGFFLPLMTITGEL IDLNQSRNHPMLGVRLNGKDAWDVHVNAVL NKRRVFPNF I CHDHS I FGFFLPLMTMTGEL IDLNQARNHPMLGVRLHGKDAWDVHVSEVL

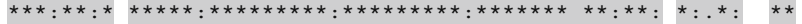

RQLEIYKASLTTFAATTAVPEAPLSTTYP - PPTPDHPVEPSLSQAFSWHTQTVIAYASYL RQLEIYKASLTTFAATAAVPEAPLATTYR-PPGPDPPVEPSLSQAFSWHTQTVIAYASYL RQLEIYKASLTTFATTAIVPDGPLPTTYG-HSSPDPSTETSLSQAFSWHTQTVIAYASYL RQLELYKASLTTFAATASDPDAPLSSAFP-PKPDQQPVEPSLAQAYSWHTQTVISYASYL ROLEIYKASLTTFAATTSDPEAPLSAYAH-AQSEHLPAEPSLSQAYAWHTQTVISYASYL GOLEIYKASLTTFAATASDPEAPLSYAYPPPKSDTNGVDPALTOAYSWHTOTVISYASYL GQLEIYKASLTTFAATASDPEAPLSYAYPPPKSDTNGVDPALTQAYSWHTQTVISYASYL RQLEIYKASLTTFAATASDPEAPFSTAYPAPKPDHP -VDPALAQAYSWHTQTVISYASYL

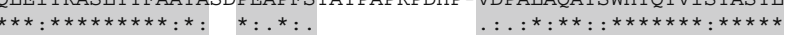

VHVLHI LLVGKWDPVSLIEDKDFWTSSPAFATTISHALDAADSVNOILRYDPDISFMPYF VHVLHILLVGKWDPVSLIEDKDFWTSSPAFATTISHALDAADSVHOILRYDPDISFMPYF VHVLHILLVGKWDPVSLIEDKDFWTSSPAFASTISHALDAADSVNQILRYDPDVSFMPYF VHVLHI LLVGKWDPVSLIEDKDFWTSSPAFASTI SHALDAADSVDHILRYDPDISFMPYF VHVLHILLVGKWDPVSLIEDKDFWTSSPAFASTISHALDAADSVDQILRYDPDISFMPYF VHVLHI LLVGKWDPVSLIEDKDFWTSSPAFASTISHALDAADSVDQILRFDPDISFMPYF VHVLHILLVGKWDPVSLIEDKDFWTSSPAFASTISHALDAADSVDOILRFDPDISFMPYF VHVLHILLVGKWDPVSLIEDKDFWTSSPAFASTISHALDAADSVNQILRFDPDISFMPYF $* * * * * * * * * * * * * * * * * * * * * * * * * * * *: * * * * * * * * * * * .: * * *: * * *: * * * * * *$

FGIQLLQGSFLLLLIVERLQKEAGEGILNACEVMIRATESCVVTLNTEYQRNFRQVMRSA FGIQLLQGSFLLLLIVERLQKEAGEGI LNACEVMIRATESCVVTLNTEYQRNFRQVMRSA FGIOLLOGSFLLLLIVERLOKEAGEGILNACEVMIRATESCVVTLNTEYORNFROVMRSA FGIQLLQGSFLLLLIVERLQKEAGEGILNACEVMIRATESCVVTLNTEYQRNFRQVMRSA FGIQLLQGSFLLLLIVERLQKEAGEGI LNACEVMIRATESCVVTLNTEYQRNFRQVMRSA FGIQLLQGSFLLLLIVERLQKEAGEGILNACEVMIRATESCVVTLNTEYQRNFRQVMRSA FGIQLLQGSFLLLLIVERLQKEAGEGILNACEVMIRATESCVVTLNTEYQRNFRQVMRSA FGIQLLQGSFLLLLIVERLQKEAGEGILNACEVMIRATESCVVTLNTEYQRNFRQVMRSA
$* * * * * * * * * * * * * * * * * * * * * * * * * * * * * * * * * * * * * * * * * * * * * * * * * * * * * * * * *$

VAQARGRPVNHSEIRHRRKAVLALYRWTRKGTGLAL VAQARGRPVNHSEIRHRRKAVLALYRWTRKGTGLAL VAQARGRPVNHSEIRHRRKAVLALYRWTRNGTGLAL VAOARGRPVNHSEIRHRRKAVLALYRWTRKGTGLAL VAQARGRPVNHSEIRHRRKAVLALYRWTRKGTGLAL VAQARGRPVNHSEIRHRRKAVLALYRWTRKGTGLAL VAQARGRPVNHSEIRHRRKAVLALYRWTRKGTGLAL VAQARGRPVNHSEIRHRRKAVLALYRWTRKGTGLAL

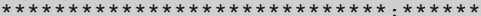


Fig. 3 Growth of the $A$. niger and $A$. nidulans reference, $\triangle \operatorname{araR}, \triangle x \ln R$ and $\triangle \operatorname{araR} /$ $\Delta x \ln R$ strains on $25 \mathrm{mM}$ D-glucose, L-arabinose, L-arabitol, D-xylose and xylitol. The $A$. niger growth data was represented from our previous study (Battaglia et al. 2011) with permission from the publisher

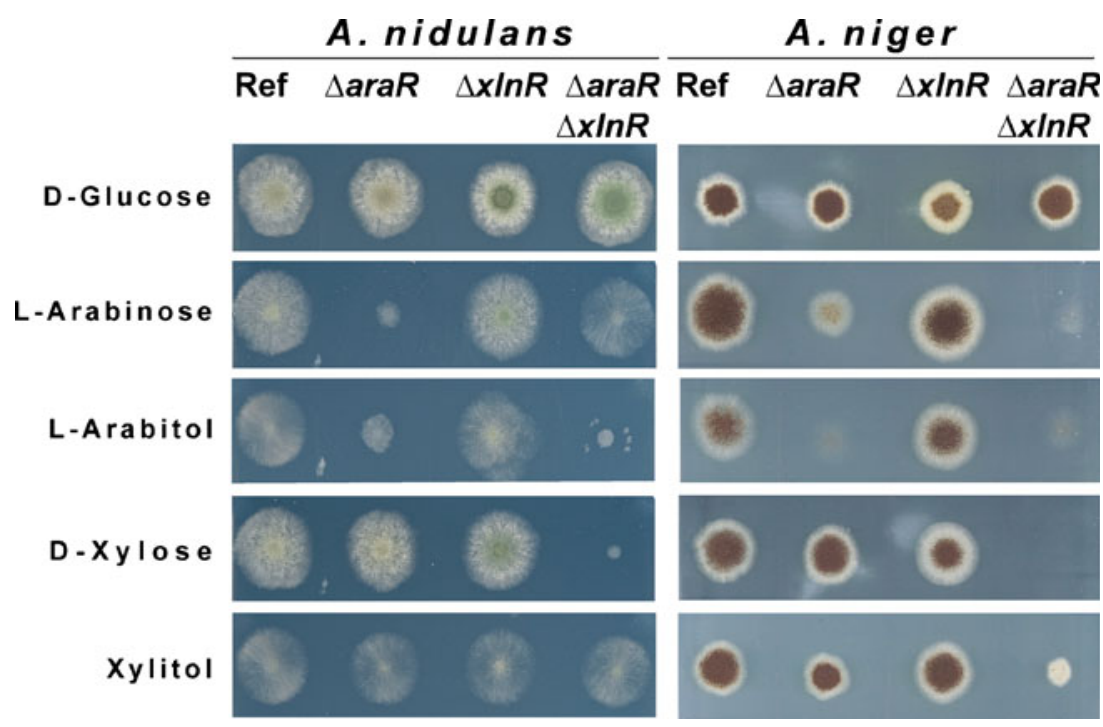

Transcriptional analysis of the pentose catabolic pathway genes

To study the regulation of the pentose catabolic pathway in A. nidulans, a transcriptional profile of the PCP genes was compared in the A. nidulans reference, $\triangle \operatorname{araR,} \Delta x \ln R$ and $\triangle \operatorname{araR} / \Delta x \ln R$ strains. To this end, a transfer experiment was performed (see the "Materials and methods" section) using the strains and the carbon sources indicated in Fig. 4. In the presence of xylitol, no or low induction was detected for any of the genes in any of the strains tested. In the reference strain, the expression of the L-arabinose specific
PCP genes (ladA, $\operatorname{lar} A, \operatorname{lx} r A$ ) was induced on L-arabinose and L-arabitol, but not on D-xylose (Fig. 4). The expression of $x y r A$ (D-xylose specific) was only observed on D-xylose, whereas the genes encoding the last two steps common in both pathways $(x d h A, x k i A)$ were induced by both L-arabinose and D-xylose.

No $x y r A$ expression was observed on D-xylose in the $\Delta x \ln R$ strain, while genes of the L-arabinose pathway $(\operatorname{lad} A, \operatorname{lar} A$ and $\operatorname{lx} A$ ) were induced. A reduced level of $x d h A$ was observed on both L-arabinose and D-xylose in the $\Delta x \ln R$ strain, while a higher expression level of both $x d h A$ and $x k i A$ was detected on L-arabitol.
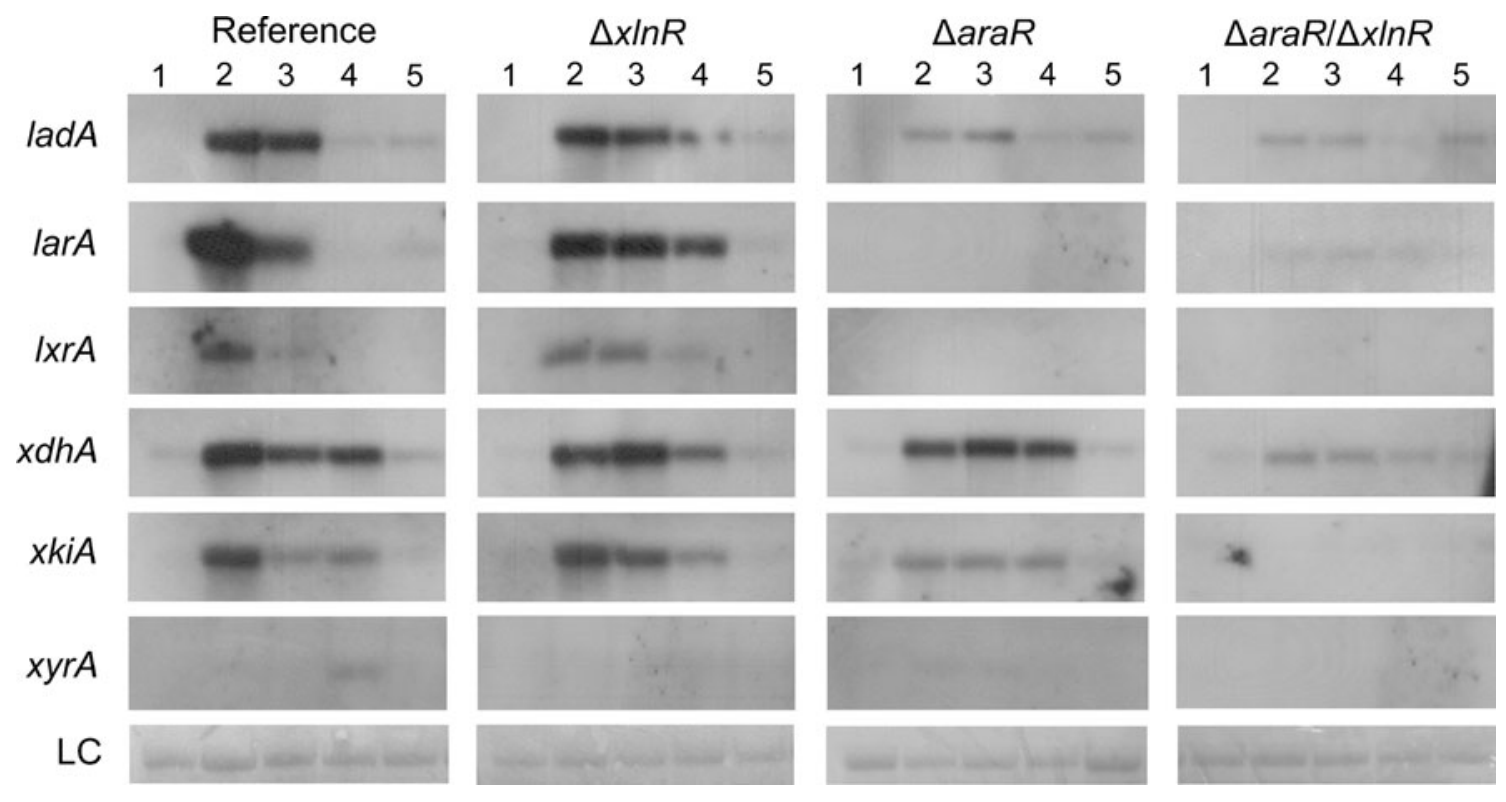

Fig. 4 Expression analysis of the A. nidulans pentose catabolic pathway genes. All A. nidulans strains were transferred to $25 \mathrm{mM}$ of the indicated carbon source for $2 \mathrm{~h}$ of growth. ladA L-arabitol

dehydrogenase, larA L-arabinose reductase, $x d h A$ xylitol dehydrogenase, xkiA xylulose kinase, xyrA D-xylose reductase, $L C$ loading control. 1 D-fructose, 2 L-arabinose, 3 L-arabitol, 4 D-xylose, 5 xylitol 
A reduced level of ladA expression was observed on Larabinose and L-arabitol in the $\triangle a r a R$ strain, and no expression of larA and $l x r A$ was detected. For $x d h A$ and $x k i A$, expression on L-arabinose was decreased in the absence of AraR. An increase of $x d h A$ expression was observed on L-arabitol, while both $x d h A$ and $x k i A$ expression levels remained unaffected on D-xylose.

Reduced, but detectable expression levels of ladA, larA and $x d h A$ were observed in the $\triangle a r a R \Delta x \ln R$ strain on L-arabinose and L-arabitol, while $x d h A$ was also expressed on D-xylose in the $\Delta \operatorname{araR} \Delta x \ln R$ strain. No $x k i A$ specific transcript was detected in a double-knockout strain under all the conditions tested.

Analysis of the activity of pentose catabolic pathway enzymes

The enzymatic activities for L-arabitol dehydrogenase (Lad), xylitol dehydrogenase (Xdh), L-arabinose reductase (Lar), Dxylose reductase (Xyr) and L-xylulose reductase (Lxr) were measured in the mycelium samples of a transfer experiment to L-arabinose and D-fructose (see the "Materials and methods" section) using the strains indicated in Fig. 5.

After $2 \mathrm{~h}$ of growth on L-arabinose, the reduced activities of Lad, Xdh, Lar, Xyr and Lxr were detected in the $A$. nidulans $\triangle$ araR strain. The results showed no Lad and Xdh activity in A. nidulans $\triangle \operatorname{araR} \Delta x \ln R$ (Fig. 5). After 4 h of growth on L-arabinose, increased activities of Xdh, Lar and Xyr were detected in the A. nidulans $\triangle a r a R$ strain, while Lxr activity was still lower than the reference strain. Only Lxr activity was decreased in the A. nidulans $\triangle \operatorname{araR} \Delta x \ln R$ strain after $4 \mathrm{~h}$ on L-arabinose, while the other activities were similar to the reference strain (Fig. 5). Very low activities of Lad, Xdh, Lar, Xyr and Lxr were observed on D-fructose in any of the strains (data not shown).

\section{Discussion}

In this study, we analysed the function of the arabinolytic regulator (AraR) in A. nidulans and compared it to the recently reported A. niger AraR (Battaglia et al. 2011). Plate growth tests revealed reduced growth of the $A$. nidulans $\triangle a r a R$ strain on L-arabinose and L-arabitol, confirming a role for AraR in L-arabinose catabolism in this species. In addition, the expression analysis confirmed that AraR predominantly controls the A. nidulans PCP genes, including the recently identified genes encoding Larabinose reductase (larA; Mojzita et al. 2010a) and Lxylulose reductase (lxrA; Mojzita et al. 2010b). However, the data presented in this paper reveals that the functional role of AraR in the PCP differs significantly in A. nidulans and $A$. niger.
Fig. 5 Comparison of intracellular enzyme activities in A. nidulans and A. niger. L-arabitol dehydrogenase (Lad), xylitol dehydrogenase (Xdh), L-arabinose reductase (Lar), D-xylose reductase (Xyr) and L-2-keto-3deoxyarabonatexylulose reductase (Lxr) activity were measured in the A. nidulans and $A$. niger reference, $\triangle a r a R$ and $\triangle \operatorname{araR} / \Delta x \ln R$ strains. The $A$. niger enzyme activity data was represented from our previous study (Battaglia et al. 2011) with permission of the publisher. The enzyme activities are given in units per milligramme of the total protein

Comparative analysis clearly shows differences between growth on L-arabinose and the PCP in the A. nidulans and A. niger $\triangle a r a R$ and $\triangle a r a R / \Delta x \ln R$ strains. The results observed in these $A$. nidulans strains can be explained by either an additional regulatory system or an alternative pathway for L-arabinose catabolism.

As A. nidulans appears to have AraR/XlnR independent and $\mathrm{L}$-arabinose-specific induction of several PCP genes (larA, ladA and $x d h A$ ), this suggests the involvement of an as-yet-unknown regulator. That this effect is not caused by a low constitutive expression level of these genes is demonstrated by the absence of expression on D-fructose. This unknown regulator may be activated by L-arabinose or its intermediate product, but appears to be dependent on the intracellular accumulation of this inducer. A similar effect was observed for XlnR (Battaglia et al, unpublished results). In the $A$. nidulans $\triangle$ araR strain on L-arabinose, $\mathrm{X} \ln \mathrm{R}$ activates the expression of xylanase genes, which does not occur in a wild-type strain. This suggests that $X \ln R$ responds to the presence of accumulated concentrations of L-arabinose or a conversion product. Such a sophisticated mode of regulation, where a pathway-specific regulator can trigger the transcription of target genes in the presence of a threshold level of an inducing molecule not directly linked to this metabolic pathway may be used by $A$. nidulans as a rescue strategy and give an additional advantage to the fungus.

BlastP analysis of AraR and $\mathrm{XlnR}$ to the A. nidulans genome gave three significant hits, AraR and $X \operatorname{lnR}$ itself and a third unknown regulator (data not shown). The function of this regulator is currently under investigation.

No expression was detected of the L-xylulose reductase encoding gene (lxrA) and xylulose kinase encoding gene (xkiA), suggesting a partially active PCP in $\Delta \operatorname{araR} / \Delta x \ln R$ strain on L-arabinose. For the utilisation of this substrate, other enzymes that can compensate for the loss of LxrA and XkiA activity must be involved. We propose that these unknown genes are not induced in the presence of XlnR because of the impaired growth of the $\triangle a r a R$ strain on Larabinose. It is currently unknown if isoenzymes exist that compensate for the reactions of the PCP in the A. nidulans. Putative paralogs of several PCP genes are present in the $A$. nidulans genome (Flipphi et al. 2009), but their biochemical function is not determined. We observed similar activities for 4 of the tested enzymes (Lar, Xyr, Lad, Xdh) in the $A$. nidulans $\triangle \operatorname{araR} / \Delta x \ln R$ and the reference strain after $4 \mathrm{~h}$ on 


\section{A. nidulans}
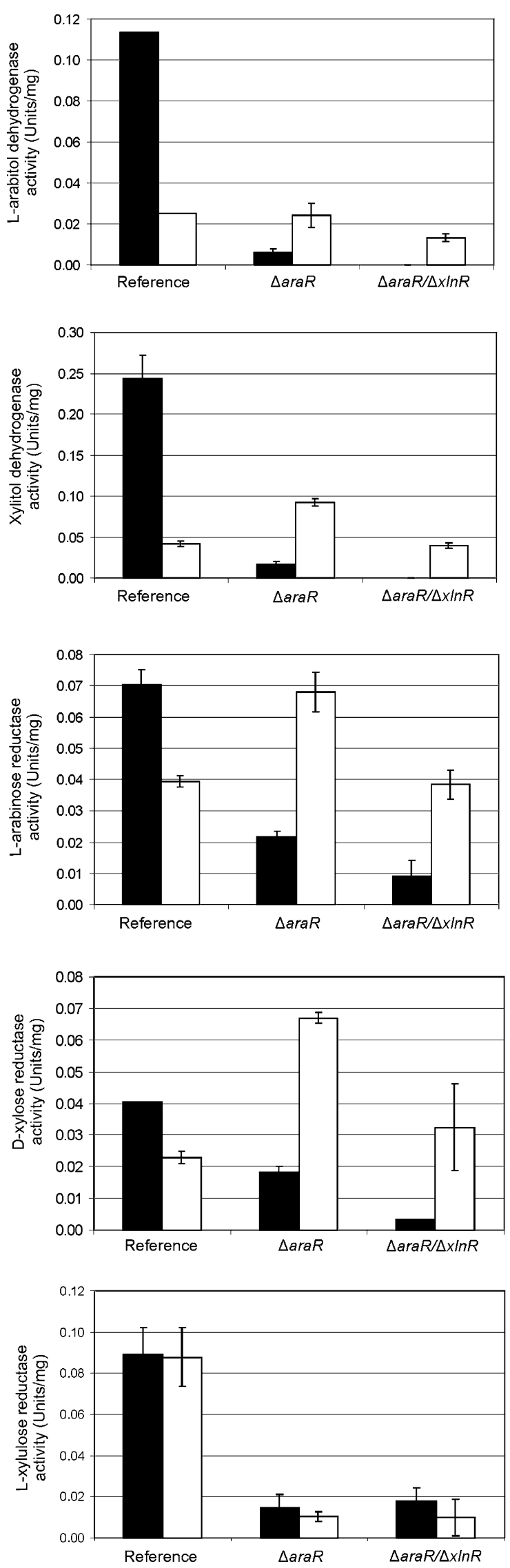

A. niger
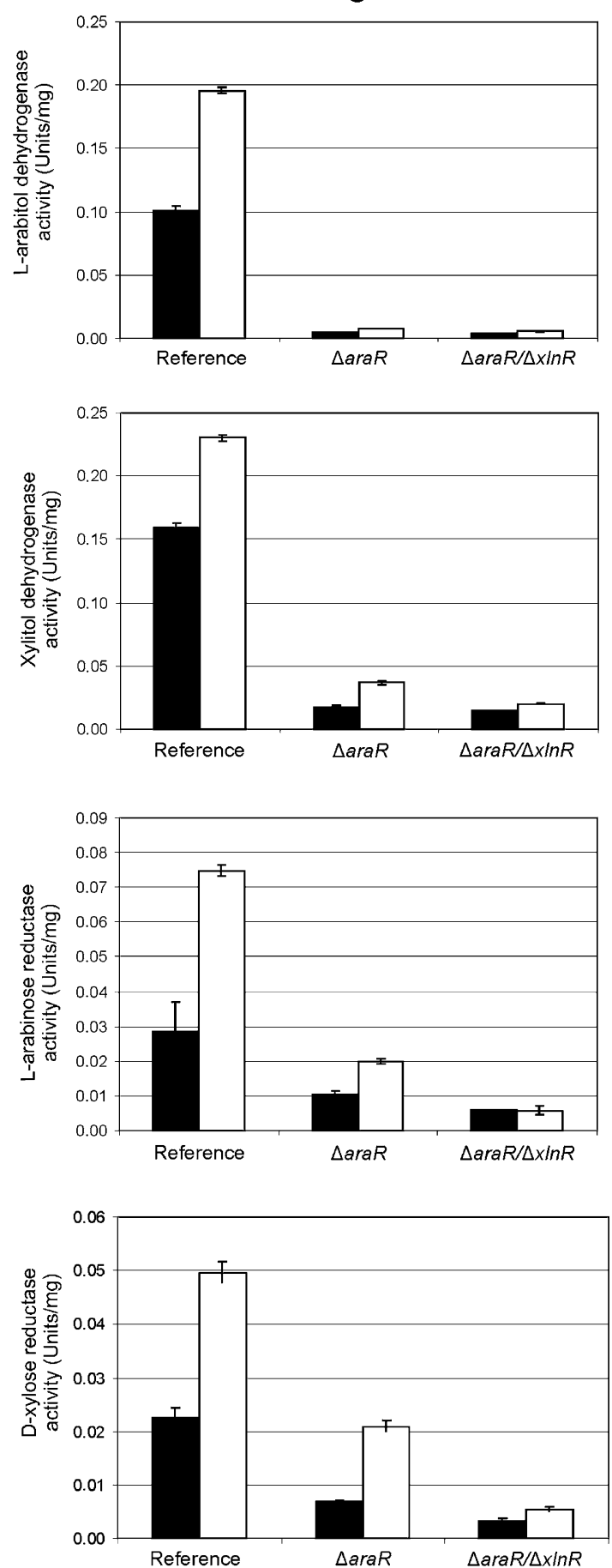

2h L-Arabinose

4h L-Arabinose 
L-arabinose, while expression of these genes was significantly reduced in the $\Delta a r a R / \Delta x \ln R$ strain. This suggests that other enzymes can in part compensate for the absence of the PCP-specific enzymes. However, this was not the case for Lxr, suggesting that growth on L-arabinose in the A. nidulans $\triangle \operatorname{araR} / \Delta x \ln R$ strain is not likely caused by isoenzymes generating a similar pathway as the normal PCP. It is therefore more likely that an alternative pathway can convert L-arabinose that may in part use similar activities as the PCP.

There is currently no evidence for the existence of an alternative fungal L-arabinose pathway and the data of our study suggests that should such a pathway exists, it is not dependent on AraR and is only activated in the absence of XlnR. Alternative pathways for carbon utilisation have been shown to exist in fungi and bacteria. A second pathway for D-galactose catabolism (the oxido-reductive pathway) was previously found in $A$. nidulans (Fekete et al. 2004). In bacteria, two L-arabinose pathways are known: the arabinose (araBAD) operon (Lee et al. 1986) and an alternative pathway through L-2-keto-3-deoxyarabonate (Watanabe et al. 2006a; Watanabe et al. 2006b).

The comparison of growth, expression and activity profiles demonstrates that the role of $\mathrm{X} \operatorname{lnR}$ in the regulation of the PCP is similar in A. nidulans and A. niger. In both Aspergillus species, it has been demonstrated that XlnR also share the same functional regulatory role with respect to extracellular D-xylose releasing enzymes (Tamayo et al. 2008; van Peij et al. 1998).

In summary, this study demonstrates that the regulatory role of AraR in the PCP differs between two Aspergilli, while this is not the case for XlnR. This may indicate that the two species optimized their carbon source utilisation by subtle, but significant variations in the catabolic pathway itself and its regulatory mechanism. It demonstrates that the influence of homologous regulatory systems in different (even related) fungi can differ significantly. This also implies that manipulating regulatory systems to improve the production of polysaccharide degrading enzymes, may give different results in different industrial fungi.

Acknowledgements EB and RPdV were supported by a grant of the Dutch Technology Foundation STW, Applied Science division of NWO and the Technology Program of the Ministry of Economic Affairs UGC 07063 to RPdV.

Open Access This article is distributed under the terms of the Creative Commons Attribution Noncommercial License which permits any noncommercial use, distribution, and reproduction in any medium, provided the original author(s) and source are credited.

\section{References}

Battaglia E, Visser L, Nijssen A et al. (2011) Analysis of regulation of pentose utilization in Aspergillus niger reveals evolutionary adaptations in the Eurotiales. Stud Mycol (in press)
Chaveroche MK, Ghigo JM, d'Enfert C (2000) A rapid method for efficient gene replacement in the filamentous fungus Aspergillus nidulans. Nucleic Acids Res 28(22):E97

Chenna R, Sugawara H, Koike T, Lopez R, Gibson TJ, Higgins DG, Thompson JD (2003) Multiple sequence alignment with the Clustal series of programs. Nucleic Acids Res 31(13):3497-3500

Crabtree J, Angiuoli SV, Wortman JR, White OR (2007) Sybil: methods and software for multiple genome comparison and visualization. Methods Mol Biol 408:93-108

de Groot MJ (2005) Regulation and control of L-arabinose catabolism in Aspergillus niger. $\mathrm{PhD}$ thesis, Wageningen University, Microbiology

de Groot MJ, van den Dool C, Wösten HAB, Levisson M, vanKuyk PA, Ruijter GJG, de Vries RP (2007) Regulation of pentose catabolic pathway genes of Aspergillus niger. Food Technol Biotechnol 45:134-138

de Vries RP, Visser J (2001) Aspergillus enzymes involved in degradation of plant cell wall polysaccharides. Microbiol Mol Biol Rev 65(4):497-522

de Vries RP, Burgers K, van de Vondervoort PJ, Frisvad JC, Samson RA, Visser J (2004) A new black Aspergillus species, A. vadensis, is a promising host for homologous and heterologous protein production. Appl Environ Microbiol 70(7):3954-3959

de Vries RP, Flipphi MJ, Witteveen CF, Visser J (1994) Characterization of an Aspergillus nidulans L-arabitol dehydrogenase mutant. FEMS Microbiol Lett 123(1-2):83-90

Fekete E, Karaffa L, Sandor E, Banyai I, Seiboth B, Gyemant G, Sepsi A, Szentirmai A, Kubicek CP (2004) The alternative D-galactose degrading pathway of Aspergillus nidulans proceeds via Lsorbose. Arch Microbiol 181(1):35-44

Flipphi M, Sun J, Robellet X, Karaffa L, Fekete E, Zeng AP, Kubiecek CP (2009) Biodiversity and evolution of primary carbon metabolism in Aspergillus nidulans and other Aspergillus spp. Fungal Genet Biol 46(Suppl 1):S19-S44

Hasper AA, Visser J, de Graaff LH (2000) The Aspergillus niger transcriptional activator $\mathrm{X} \ln \mathrm{R}$, which is involved in the degradation of the polysaccharides xylan and cellulose, also regulates D-xylose reductase gene expression. Mol Microbiol 36(1):193-200

Lee N, Gielow W, Martin R, Hamilton E, Fowler A (1986) The organization of the araBAD operon of Escherichia coli. Gene 47 $(2-3): 231-244$

Marmorstein R, Harrison SC (1994) Crystal structure of a PPR1-DNA complex: DNA recognition by proteins containing a $\mathrm{Zn} 2 \mathrm{Cys} 6$ binuclear cluster. Genes Dev 8(20):2504-2512

Marmorstein R, Carey M, Ptashne M, Harrison SC (1992) DNA recognition by GAL4: structure of a protein-DNA complex. Nature 356(6368):408-414

Mojzita D, Penttilä M, Richard P (2010a) Identification of an Larabinose reductase gene in Aspergillus niger and its role in Larabinose catabolism. J Biol Chem 285(31):23622-23628

Mojzita D, Vuoristo K, Koivistoinen OM, Penttilä M, Richard P (2010b) The 'true' L-xylulose reductase of filamentous fungi identified in Aspergillus niger. FEBS Lett 584(16):3540-3544

Sambrook J, Russell D (2001) Molecular cloning - a laboratory manual, 3rd edn. Cold Spring Harbor Laboratory Press, Cold Spring Harbor

Suarez T, de Queiroz MV, Oestreicher N, Scazzocchio C (1995) The sequence and binding specificity of UaY, the specific regulator of the purine utilization pathway in Aspergillus nidulans, suggest an evolutionary relationship with the PPR1 protein of Saccharomyces cerevisiae. EMBO J 14(7):1453-1467

Swaminathan K, Flynn P, Reece RJ, Marmorstein R (1997) Crystal structure of a PUT3-DNA complex reveals a novel mechanism for DNA recognition by a protein containing a $\mathrm{Zn} 2 \mathrm{Cys} 6$ binuclear cluster. Nat Struct Biol 4(9):751-759 
Tamayo EN, Villanueva A, Hasper AA, de Graaff LH, Ramon D, Orejas M (2008) CreA mediates repression of the regulatory gene $x \ln R$ which controls the production of xylanolytic enzymes in Aspergillus nidulans. Fungal Genet Biol 45(6):984-993

Tilburn J, Scazzocchio C, Taylor GG, Zabicky-Zissman JH, Lockington RA, Davies RW (1983) Transformation by integration in Aspergillus nidulans. Gene 26(2-3):205-221

Todd RB, Davis MA, Hynes MJ (2007) Genetic manipulation of Aspergillus nidulans: meiotic progeny for genetic analysis and strain construction. Nat Protoc 2(4):811-821

van Peij NN, Visser J, de Graaff LH (1998) Isolation and analysis of $x \ln R$, encoding a transcriptional activator co-ordinating xylanolytic expression in Aspergillus niger. Mol Microbiol 27(1):131-142

vanKuyk PA, de Groot MJ, Ruijter GJ, de Vries RP, Visser J (2001) The Aspergillus niger $\mathrm{D}$-xylulose kinase gene is co-expressed with genes encoding arabinan degrading enzymes, and is essential for growth on D-xylose and L-arabinose. Eur J Biochem 268(20):5414-5423
Vieira J, Messing J (1991) New pUC-derived cloning vectors with different selectable markers and DNA replication origins. Gene 100:189-194

Walters KJ, Dayie KT, Reece RJ, Ptashne M, Wagner G (1997) Structure and mobility of the PUT3 dimer. Nat Struct Biol 4(9):744-750

Watanabe S, Kodaki T, Makino K (2006a) Cloning, expression, and characterization of bacterial L-arabinose 1-dehydrogenase involved in an alternative pathway of L-arabinose metabolism. J Biol Chem 281(5):2612-2623

Watanabe S, Shimada N, Tajima K, Kodaki T, Makino K (2006b) Identification and characterization of L-arabonate dehydratase, L-2-keto-3-deoxyarabonate dehydratase, and L-arabinolactonase involved in an alternative pathway of L-arabinose metabolism. Novel evolutionary insight into sugar metabolism. J Biol Chem 281(44):33521-33536

Witteveen CFB, Busink R, Van de Vondervoort PJI, Dijkema C, Swart K, Visser J (1989) L-arabinose and D-xylose catabolism in Aspergillus niger. J Gen Microbiol 135:2163-2171 